\title{
FLORENCE, POPE CLEMENT VII AND EMPEROR CHARLES V. A CONTEXTUAL STUDY OF THE MOTET 'DOMINATOR CAELORUM' BY JEAN CONSEIL / COSTANZO FESTA (?)*
}

\begin{abstract}
7 he five-voice motet Dominator caelorum is ascribed to Costanzo Festa (c.1490-1545) only in the well-known Roman manuscript Biblioteca Vallicelliana, MS S.I 35-40 (olim Vall. S. Borr. E.II 55-60), probably copied in Florence between I530 and I53I. ${ }^{\mathrm{I}}$ It is found there among four other motets by Festa. ${ }^{2}$ In two other sources it is ascribed to Jean Conseil (c.I498-I534), ${ }^{3}$ and it is found with no composer's name in three others. ${ }^{4}$ Because of the authority of the Vallicelliana manuscript, the work is included in Festa's Opera Omnia. ${ }^{5}$ Hence for most of this article the motet is referred to as Festa's composition.
\end{abstract}

* Kenneth Kreitner deserves special thanks for his insightful comments on sections of this article and for his professional advice. Of course, any and all errors or shortcomings in this work are mine alone.

I For a description of the source and its contents, see Edward E. Lowinsky, 'A newly discovered sixteenth-century motet manuscript at the Biblioteca Vallicelliana in Rome', Journal of the American Musicological Society 3 (1950) no. 3, pp. I73-232. Although its Florentine provenance is generally accepted, Anne-Marie Bragard suggested that it might have been produced in Rome. On the origin of the manuscript, see E.E. Lowinsky, op. cit., pp. 195-196; for an overview of Lowinsky's and Bragard's interpretation, see H. Colin Slim, A gift of madrigals and motets, Chicago 1972, vol. I, pp. 56-65; see also Census-catalogue of manuscript sources of polyphonic music I400-I550, eds. Charles Hamm and Herbert Kellman, vol. 3, [Rome] I984, pp. II9-I2O.

2 The other four are Florentia tempus est penitentia (5vv.), Deus venerunt gentes (5vv.), Laetemur omnes (6vv.), and Exaltabo te Domine (6vv.).

3 RISM $1539^{8}$, no. 4 and BolC Q27, fol. 46v; on the basis of these two sources the motet is attributed to Conseil in John T. Brobeck, The motet at the court of Francis I, PhD dissertation, University of Pennsylvania I99I, p. 496.

4 FlorD 4, fols. 95v-99r, PadBC D27, fol. 79v, Meijer partbook, fols. 77v-79r. For a description of the last source, see Eric Jas, 'A sixteenth-century Ferrarese partbook from a private collection', Tijdschrift van de Koninklijke Vereniging voor Nederlandse Muziekgeschiedenis 52 (2002), pp. 35-65.

5 Costanzo Festa: Opera Omnia, ed. Albert Seay, vol. 5, [Rome] I979, pp. I20-126, for a commentary on the motet, see p. xviii. Main considers the work as doubtful because of conflicting attributions, but he admits that it could be by Festa; see Alexander Main, Costanzo Festa: The masses and motets, PhD dissertation, University of New York 1960, p. 63. 
The Vallicelliana partbooks include a number of motets that refer to important political events; Edward Lowinsky has pointed out that at least a few of these motets constitute a true historical chronicle in music. ${ }^{6}$ For example, Festa's Florentia may have been composed after the sack of Rome in 1527 , when Florentines revolted and attempted to get rid of the ruling Medici family, or could refer to the siege of Florence between I529 and 1530. ${ }^{7}$ Festa's setting of Psalm 78 might refer to the destruction and devastation of Rome during the so-called sacco di Roma while his Exaltabo te domine is believed to have been written for the agreement between Pope Clement VII and Charles V, or later after the defeat of Florence. ${ }^{8}$ There is also a group of twenty-five compositions addressed to the Virgin Mary. ${ }^{9}$ Some of the other motets in the Vallicelliana manuscript may have been composed either to commemorate the memory of Girolamo Savonarola (I452-98) ${ }^{\mathrm{IO}}$ or to

6 E.E. Lowinsky, op. cit., p. I75.

7 Ibid., pp. I79-I80; Richard Sherr, 'Clement VII and the golden age of the papal choir', in: The pontificate of Clement VII: History, politics, culture, eds. Kenneth Gouwens and Sheryle E. Reiss, Burlington 2005, p. 246.

8 E.E. Lowinsky, op. cit., pp. I80-I82.

9 Willem Elders points out that the number of motets dedicated to Mary is much bigger than the number of motets commemorating Savonarola. He also observes that there is a group of motets by composers - Willaert and Jachet of Mantua - whose connection with Florence has not been traced yet. All this permits us to have doubts linking the manuscript with Florence; see Willem Elders, Symbolic scores. Studies in the music of the Renaissance, Leiden I994, p. 82. But it is sufficient for the purpose of this study to state that the motets to the Virgin so largely represented in the Vallicelliana manuscript might be a reflection of the situation in which the Florentines found themselves between I527 and 1530. From documents it is known that the Florentines sought help from the Virgin Mary in these times. For example, during a horrible epidemic of 1527 the Cardinal Archbishop ordered that all citizens should kneel in prayer at the sounding of the Ave Maria. On I8 August the picture of the Madonna from Impruneta was brought to the city. It was solemnly greeted by the Signoria at the city gates who accompanied it to the Church of the Annunziata; see Cecil Roth, The last Florentine Republic, New York 1968, pp. 75-76; the black image of the Virgin of the Impruneta was particularly venerated by the Florentines. Impruneta, the site of this miraculous picture, is around seven miles from the Porta Romana. Every time her help was needed she was brought to Florence. For example, in February I499 'Our Lady was brought in order to inspire the Signoria to choose the correct political course and in October 1529, with the Republic under siege by Imperial forces, the government decided to bring in the Virgin, concerned first of all that such an important source of power not fall into the hands of the besiegers. She was smuggled past the enemy, through the suburbs and into the city. Solemnly met at the gate and accompanied to the cathedral, she was placed in the chapel of San Zanobi'; see Richard C. Trexler, 'Florentine religious experience: The sacred image', Studies in the Renaissance 19 (1972), pp. I5-I6. The Madonna of Impruneta was also brought to Florence on the election of Cardinal de' Medici as Leo X (II March I5I3), see Melissa Mariam Bullard, Strozzi and the Medici: Favor and finance in the sixteenth-century Florence and Rome, New York 1980, p. 72. It does not seem unreasonable to suggest that some of the Marian motets in the manuscript may have been inspired by the presence of the Virgin of Impruneta in Florence (e.g. some of Lhéritier's motets).

IO This was probably due to the fact that long after Savonarola's death his writings, sermons and favorite psalms were still vividly remembered among the Florentines, and their meaning and connotations were of course easily associated with current political situations. On Savonarola’s influence on music, see M.M. Bullard, op. cit., pp. I84-I87; Johannes Lhéritier: Opera Omnia, ed. Leeman L. Perkins, [Rome] 1969, p. xvii; H.C. Slim, op. cit., vol. I, pp. 70-74; Patrick Macey, 'Savonarola and the sixteenth-century motet', Journal of the American Musicological Society 36 (1983) no. 3, p. 422; idem, 'The lauda and the cult of Savonarola', Renaissance Quarterly 45 (1992) no. 3, pp. 439-483; Michele Fromson, 'Themes of exile in Willaert's Musica Nova', Journal of the American Musicological Society 47 (1994) no. 3, pp. 442-487, esp. 454-465; Savonarolan laude, motets, and anthems, ed. Patrick Macey, Madison 1999 (= Recent Researches in the Music of the Renaissance II6), pp. ix-xxi. The most comprehensive study of the problem is Patrick Macey, Bonfire songs: Savonarola's musical legacy, New York 1998. 


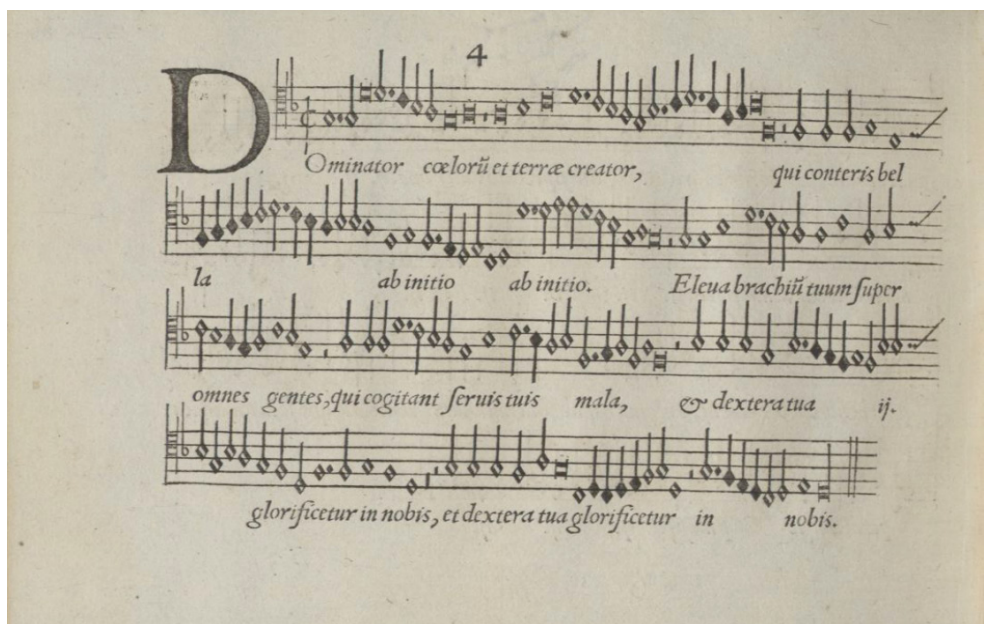

Fig. I. Jean Conseil/Costanzo Festa?, motet Dominator caelorum, no. 4, cantus Cantiones quinque vocum selectissimae, Straßburg I539 [= RISM I539 ${ }^{8}$.

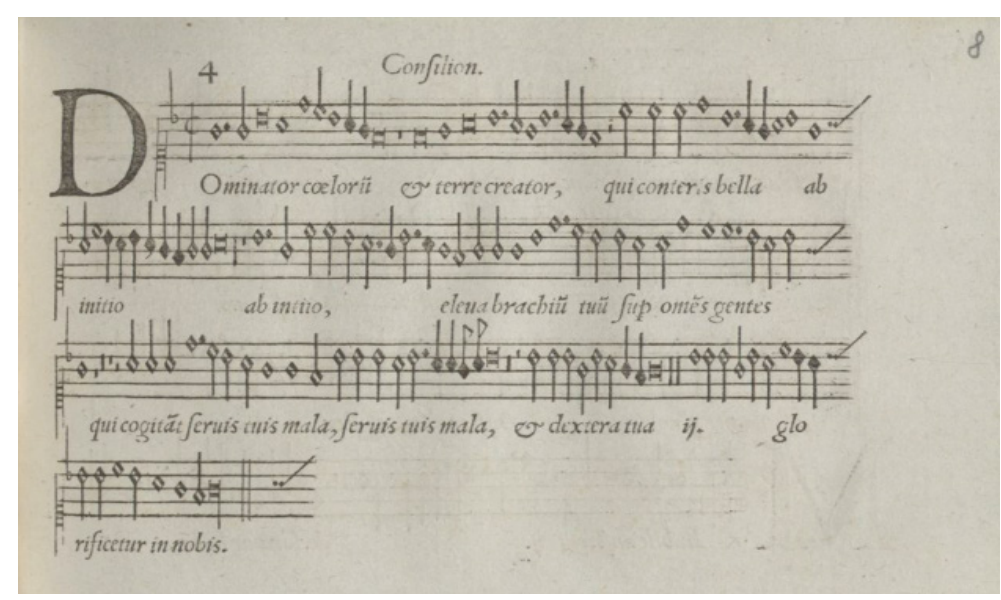

Fig. 2. Jean Conseil/Costanzo Festa?, motet Dominator caelorum no. 4, tenor Cantiones quinque vocum selectissimae, Straßburg I539 [= RISM I539 $9^{8}$.

refer to the siege of Florence. Lowinsky suggests that seventeen of the ninety works in the

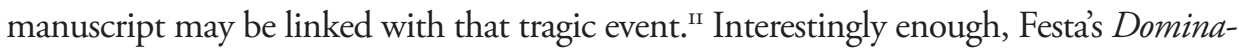
tor caelorum has never been included in any of these groups, nor was it even mentioned in Lowinsky's initial article about the manuscript. ${ }^{12}$

II E.E. Lowinsky, op. cit., p. I92.

I2 The reason for this is that Lowinsky's study was not intended to be a full account of the content of the Vallicelliana manuscript and thus some of the motets were omitted in discussion. 
Of Festa's five motets in the Vallicelliana, only Dominator caelorum and Florentia ${ }^{13}$ do not have concordances with the manuscript Biblioteca Apostolica Vaticana, Capella Sistina, VatS 20. ${ }^{\mathrm{I}}$ The absence of Dominator caelorum and Florentia in RVat 20, the major source for Festa's motets, seems to be conspicuous and surprising. If it means that Festa himself did not provide these two motets to be included in the RVat 20 to Johannes Parvus, the main scribe for the Cappella Sistina, how then should Dominator caelorum be viewed? ${ }^{\text {s }}$ Lowinsky points out that:

the Sistine manuscripts written for the official use of the Papal Chapel tended in general to exclude works whose local and historical limitation was so obvious that their use was restricted to one occasion only. For this reason Festa's political message to Florence [the motet Florentia tempus est penitentiae] is not to be found in the manuscripts of the Sistine Chapel, while the settings of Psalms 78 [Deus venerunt gentes] and 29 [Exaltabo te Domine] are included in Codex Cap. Sist. 20. ${ }^{16}$

Such an argument cannot, however, be used to explain the absence of Dominator caelorum, which, despite some variations, has a liturgical derivation and could be viewed in the same way as many other motets in the Vallicelliana. It shall be shown that its function and role may be determined by comparing Dominator caelorum with one of the anonymous motets in the manuscript VatS 20. But first it is necessary to look at the motet text derived from the Book of Judith and the historical context of this book, and to give a brief overview of the role Judith played in symbolic and narrative traditions.

The motet Dominator caelorum consists of two movements. The text of the four texted voices (Cantus, Altus I, Tenor, Bassus) in the first movement and the first line of the second movement, except for slight alterations, comes from the Book of Judith, from the famous chapter 9, in which Judith prostrated herself, put ashes on her head and said a long prayer to God for help. The middle part, Altus II, has a separately, texted cantus firmus. It carries the text and the music from the antiphon for peace Da pacem Domine. ${ }^{17}$ In each of the parts it is heard only once, and there are only slight rhythmic and melodic differences between these two statements.

I3 The work also appears in a few other sources. In TrevBC 36 it is likewise with the text Florentia tempus est penitentie; see Edward E. Lowinsky, 'The Medici Codex: A document of music, art, and politics in the Renaissance', Annales musicologiques 5 (I957), pp. II3-II4. In prints RISM I537 ${ }^{1}, \mathrm{I}_{53} 8^{2}, \mathrm{I} 539^{4}, \mathrm{I}_{542^{4}}, \mathrm{I} 559^{\mathrm{I}}$ there is a contrafactum of this work with the text Hierusalem quae occidis prophetas; see Costanzo Festa: Opera Omnia, op. cit., vol. 5, pp. xiii, xvii.

I4 The sigla of the manuscripts follow the Census-catalogue (see above, n. I).

I5 Brauner says that Festa himself provided Parvus with his best works for the books VatS i8 and VatS 20; see Mitchell P. Brauner, 'Music from the Cappella Sistina at the Cappella Giulia', Journal of Musicology 3 (1984) no. 3, pp. 287-3II at 304-305. More about the attribution of the motet below.

I6 E.E. Lowinsky, 'A newly discovered', op. cit., p. I82.

I7 Liber usualis, I867-68. 
The combination of these two texts provides a message of prayer for divine help and for peace. The text of the motet goes as follows:

I.

Dominator caelorum et terrae creator

Qui conteris bella ab initio

Eleva brachium tuum super omnes gentes

Qui cogitant servis tuis mala

Et dextera tua gloricicetur in nobis.

II.

Allide fortitudinem illorum in virtute tua

Et libera nos propter nomen tuum

Et da nobis pacem in diebus nostris

Quia non est alius

Quia pugnet pro nobis

Nisi tu Deus noster.
I.

Ruler of heaven and creator of Earth Who destroys wars from the beginning Lift up your arm against all the people Who intend evil towards your people And Your right hand will be glorified in us?

II.

Crush their power with your power And deliver us for thy name's sake And grant us peace in our time There is no other Who would fight on our behalf Except you, our Lord.

Cantus firmus (Altus II):

Da pacem, Domine, in diebus nostris: quia non est alius qui pugnet pro nobis, nisi tu, Deus noster.

Give peace, O Lord, in our time because there is no one else who would fight on our behalf except you, our Lord.

In the Middle Ages some parts of the Book of Judith were read during Rogations in the Gallican church; this type of service was intended for praying to God for help. ${ }^{\mathrm{I}}$ Also, Judith texts became a part of the liturgy of certain Marian feasts and were read during the service of matins in the Divine Office. ${ }^{19}$ The text on which Festa's motet is mostly based comes from the third responsory for Judith. ${ }^{20}$

R. Domine deus, qui conteris bella ab initio, eleva brachium tuam super gentes quae cogitant servis tuis mala, et dextera tua glorificetur in nobis.

V. Allide virtutem eorum in virtute tua, cadat virtus eorum in iracundia tua. ${ }^{2 \mathrm{I}}$

I8 Ruth Steiner, 'Gregorian responsories based on texts from the Book of Judith', in: Music in medieval Europe: Studies in honour of Bryan Gillingham, eds. Terence Bailey and Alma Santosuosso, Burlington, VT 2007, pp. 23-34 at 32.

I9 Elena Ciletti, 'Patriarchal ideology in the Renaissance iconography of Judith', in: Refiguring women: Perspectives on gender and the Italian Renaissance, eds. Marilyn Migiel and Juliana Schiesari, Ithaca I99I, pp. 35-70 at 42; Kelley Harness, Echoes of women's voices: Music, art, and female patronage in early modern Florence, Chicago 2006, p. II4; R. Steiner, op. cit., p. 24.

20 It needs to be remembered that there are some variations in the order of the responsories in different sources; see R. Steiner, op. cit., pp. 26-29.

2I Ibid., p. 33 . 
This text seems to have enjoyed a great popularity among Renaissance composers, as besides Festa's there are settings of this responsory by Johannes de Bacchius, Thomas Crecquillon, Giovanni Pierluigi da Palestrina, Costanzo Porta and Philippe Verdelot. At least two of these composers - Palestrina and Porta - set exactly the first part of the responsory (R.). ${ }^{22}$ Festa seems to have been the only composer who did not use the responsory text verbatim and decided to introduce some slight changes in it: instead of 'Domine Deus, qui conteris bella ab initio', Festa starts the motet with the verse 'Dominator caelorum et terrae creator', which probably comes from the first verse of the fourth responsory, but again he does not quote it exactly. The text of the fourth responsory follows as:

R.4. Dominator domine coelorum et terrae, creator quarum, rex universae creatura tua, exaudi orationem servorum tuorum.

$\mathrm{V}$. Tu, domine, cui humilium simper et mansuetorum placuit. ${ }^{23}$

The reason for introducing some changes may have been that he wanted to signal some message, or that the motet was intended for some specific context. I shall return to this problem later.

The Book of Judith starts when King Nebuchadnezzar of Assyria, together with a coalition of nations, goes to war against the great Median king Arphaxad. ${ }^{24} \mathrm{Nebu}-$ chadnezzar defeats Arphaxad, but because there are still some pockets of resistance, the king orders Holofernes, his highest-ranking general, to destroy all rebellious spirit. When the Israelites hear about it they begin to prepare for war. In towns such as Bethulia people turn to God for help; they fast and pray. At that time, Achior, commander of the Ammonites, warns Holofernes that God will help and defend the Israelites so long as they are faithful. Holofernes, however, disregarding the warning, surrounds the Israelites in the town of Bethulia. The entire Assyrian army besieges the town for thirty-four days. All the water reserves are depleted for all the inhabitants; the cisterns are going dry. The children become listless and weak. People start to faint and die from thirst. They wonder if God has abandoned them and beg their leader Uzziah to surrender and accuse him of not making peace with the Assyrians. He says that if God does not help them within five days he will surrender.

When Judith, the religious, wealthy and beautiful daughter of Merari, hears about the compromise she becomes very upset. She says that God can do what he wants and nobody can blackmail or give Him an ultimatum, and insists that people should always be faithful to and show their confidence in their God because He has tested

22 I had access only to Palestrina's and Porta's settings, so it is possible that unlike Palestrina and Porta the remaining composers - Johannes de Bacchius, Thomas Crecquillon, and Philippe Verdelot - may have set the entire responsory.

23 R. Steiner, op. cit., p. 34.

24 The paragraph below was derived from Carey A. Moore, Judith: A new translation with introduction and commentary, Garden City, NY 1985 (= The Anchor Bible 40), pp. 3I-37. 
His people many times. Besides, she reveals her secret plan of saving the citizens of Bethulia from being killed by Holofernes' soldiers. But before she carries it out she needs to prepare herself and ask God for help. She starts her long prayer (chapter 9). After that she goes into the camp of the Assyrians, captivates Holofernes with her beauty, and finally takes advantage of the general being drunk to cut off his head. She comes back to the city with his head as a trophy. The book closes with a hymn to the Almighty sung by Judith to celebrate her victory.

The interpretation of the Book of Judith faces some problems, as it is often interpreted as a moral tale rather than an accurate historical document. In the writings of early Christians, Judith is often viewed as an allegorical figure: 'her victory over Holofernes', as Sarah McHam has put it, 'was elaborated as the triumph of virtue, specified variously as self-control, chastity, or humility, over the vices of licentiousness and pride'. ${ }^{25}$ She was often presented as a prefiguration of the Virgin Mary and of the Church. ${ }^{26}$ But one of the most popular renderings of the Book of Judith was political: her assassination of Holofernes was used as a symbolic act against tyranny and to support political aspirations, sometimes by opposing factions.

She played such a role in the history of Renaissance Florence 'as both a pro-Medici and anti-Medici symbol'. ${ }^{27}$ McHam demonstrates from the examples of Donatello's bronzes David and Judith and Holofernes how the symbolic and rhetoric meaning of these two sculptures, actually evoking republican themes, was assimilated by the Medici family for their political purposes: they helped to create an imagery of the Medici as defenders of Florence and of Florentine liberty against any threat. ${ }^{28}$ The sculptures were put in the Medici Palace garden and courtyard by I469, or even earlier, between I464 and I466. Judith and Holofernes stood there until I495, after the expulsion of the Medici from Florence the year before, ${ }^{29}$ when it was removed from the Medici Palace and placed in a conspicuous public spot on the Palazzo della Signoria, in front of the Palazzo Pubblico, as a symbol of the triumph of freedom over tyranny and with a new Latin inscription: 'Placed by the Citizens as an Example of Public Health I495' ${ }^{30}$ This was around the time that Savonarola made a famous speech on 20 August 1496 in which he praised the new government. According to Piero Misicattelli, Savonarola was viewed as the Florentines' hero who corresponded to the proud image of Judith. Like her, Savonarola was seen

Sarah Blake McHam, 'Donatello's bronze "David" and "Judith" as metaphors of Medici rule in Florence', The Art Bulletin 83 (200I) no. I, pp. 32-47 at 35 .

26 Ibid.; K. Harness, op. cit., pp. II3-II4.

27 K. Harness, op. cit., p. II5.

28 S.B. McHam, op. cit., pp. 4I, 43; for a description of the sculptures, see Bonnie A. Bennett and David G. Wilkins, Donatello, Mt. Kisco, NY 1985, pp. 217-22I.

29 B.A. Bennett and D.G. Wilkins, op. cit., p. 32.

30 'EXEMPLUM SAL PUB CIVES POS MCCCCXCV'; see K. Harness, op. cit., p. II7. 
as their liberator. ${ }^{3 \mathrm{I}}$ Because of its earlier connotations, over the next several years, the sculpture of Judith was often relocated and its meaning was debated by the Florentines; but in spite of this, David and Judith 'remained linked as emblems of Florence, specifically as symbols of the decisive way in which the city dealt with outside aggression'. ${ }^{32}$ Elena Ciletti says that 'Judith's evolution toward a Florentine civic identity is not particularly surprising, given the overtly political nature of the biblical story itself. It is also a function of her long-standing pairing (both visual and conceptual) with David, who came to assume the status of a virtual patron saint in Renaissance Florence'. 33

As an official composer of Clement VII, as Lowinsky calls him, Festa reached for the text from the Book of Judith knowing what symbolic connotations it carried. The figure of Judith and her symbolic meaning were well known in Florence, and her role as a civic symbol and a warning to all tyrants and enemies to the city was very vivid among the Florentines. ${ }^{34}$ Roger J. Crum says that 'Donatello, the Medici, and their contemporaries knew the Book of Judith, as they knew Augustine, and Dante'.35 We know that for Florentines the story of Judith could have represented the defense of republicanism against foreign enemies or tyranny; but on the other hand, for the Medici, Judith's figure may have represented their concern for Florentine liberty. ${ }^{36}$ Pope Clement VII, as a representative of the Medici family, expressed this idea clearly in November 1529 at the time when Charles V's and papal forces were besieging Florence; when the Florentine ambassadors reproached him for being too cruel to the Florentines, Clement replied that he was not fighting against the liberties of Florence but against its governors, 'who were impious tyrants'. ${ }^{37}$ The idea of insinuating that the Medici were defenders of Florentine liberty was clearly embodied in the figure of Judith.

Thus if one looks at Festa's Dominator caelorum through the prism of such political connotation, one will understand the way it might have been read by Festa and Pope Clement VII. By choosing the text from the Book of Judith, Festa shows that he sees the current political situation - during which the Medici were expelled from

3I Piero Misciattelli, Savonarola, New York 1930, p. II2.

32 K. Harness, op. cit., p. II7-II8.

33 E. Ciletti, op. cit., p. 58.

34 The symbolic image of Judith was used in Florence on different occasions; Judith appears on Ghiberti's famous baptistery doors. Also, on a page from an antiphonary of around $1508-26$, there is a figure of Judith with symbols and mottos of the Florentine republic, see K. Harness, op. cit., p. II8; the representation of Judith as a decoration appeared on one of the triumphal arches symbolizing the virtue of 'Fortezza' during Leo's Florentine entrata in I515; see Anthony Cummings, The politicized muse: Music for Medici festivals, I5I2-I537, Princeton I992, p. 72.

35 Roger J. Crum, 'Severing the neck of pride: Donatello's "Judith and Holofernes" and the recollection of Albizzi shame in Medicean Florence', Artibus et Historiae 22 (200I), pp. 23-29 at 28.

36 Ibid., p. 23.

37 Francis A. Hyett, Florence: Her history and art to the fall of the Republic, London I903, p. 5II; Hyett refers to Bernardo Segni's Storie fiorentine, G. Vanni, I835, p. 94. 
Florence and a republic was re-established - with Pope Clement's eyes. When the motet text says 'lift up your arm against all the people who intend evil towards your people' and 'crush their power with your power', Festa means, like Clement, that all those who were for re-establishing a republic were enemies and a threat to Florentine liberty and its citizens, and that this is why they should be punished. While Florentia had a form of encouragement to the Florentines to free themselves from the new government and to return under the Medicis' rule, Dominator caelorum is a prayer for punishing the new government and its supporters. But if it is a prayer to Christ, can it still have some other connotations?

There is another motet by Festa, Ecce advenit dominator, with a cantus firmus 'Christus vincit, Christus regnat, Christus imperat' stated five times in the tenor, which most likely was composed to glorify Charles $\mathrm{V}$ and may have been performed during his coronation as Holy Roman Emperor by Pope Clement VII on 24 February 1530 , still during the siege of Florence..$^{38}$ Klaus Pietschmann's thorough study of Ecce advenit dominator shows that the motet might have been performed at the central moment of the coronation and:

it would have supplemented the liturgy in a highly symbolic way: the concept allied with direct homage of the emperor to Christ without the pope as middleman was eliminated by Innocent III in order to place the papacy over the emperor in the theological hierarchy. The indirect reintroduction of this concept through Festa's motet would have brought Charles much nearer to the pope in hierarchical terms. That such a gesture by Pope Clement VII toward the emperor appears imaginable is made clear when viewed before the background of the impoverished position of the Medici pope following the sack of Rome in $1527 .{ }^{39}$

Although the formula 'Christus vincit' indicates that the motet was probably performed during the coronation, its connection with this ceremony is not so obvious. Pietschmann points out that this formula was no longer used around 1530 and had been replaced by another one which did not contain the 'Christus vincit' call. ${ }^{\circ}$ Thus he attempted to find more evidence pointing to Charles V's coronation.

38 The motet is preserved anonymously in two sources: VatS 20 and the Civitanova Marche, Biblioteca Comunale, Mss. s.s. (I). In the latter source, which can be dated from I550 to I560, the text of the cantus firmus reads 'Carolus vincit, Carolus regnat, Carolus imperat'; see Costanzo Festa: Opera Omnia, op. cit., vol. 3, p. xiii; Klaus Pietschmann, 'A motet by Costanzo Festa for the coronation of Charles V', Journal of Musicological Research 2I (2002) no. 4, pp. 319-354, esp. 326. It is also suggested that the motet might have been performed during the Roman visit of Charles V in April I536, or when he stayed in Florence in May of the same year; see Philippe Canguilhem, 'Lorenzo Corsini's "Libri di canzone" and the madrigal in mid-sixteenth-century Florence', Early Music History 25 (2006), pp. I-57 at 37 and n. IIo. At one point the motet was thought to have been composed for the coronation of Pope Clement VII; see Costanzo Festa: Opera Omnia, op. cit., vol. 3, p. xiii.

39 K. Pietschmann, op. cit., pp. 319-320.

40 A study in which the formula 'Christus vincit' is extensively discussed and to which Pietschmann often refers to is Ernst H. Kantorowicz, Laudes regiae: A study in liturgical acclamations and medieval ruler worship, Berkeley 1958. 
According to Pietschmann, the text itself may give some hint that the motet was really performed during that ceremony. The main text of the motet goes as follows:

Ecce advenit dominator dominus et regnum eius in manu eius et potestas et imperium Super humeros eius et vocabitur magni consilii angelus dorminabitur a mari usque ad mare et a flumine usque ad terminus orbis terrarum

a solis ortu usque ad occasum

laudabile nomen Domini et replebitur in aeternum majestate eius omnis terra, fiat, fiat.
Behold, the ruler, the lord is come, and a kingdom in his hand and power and dominium Upon his shoulders and he shall be called angel of great counsel He shall have dominion from sea to sea and from the river unto the ends of the earth from the rising sun to the going down of the same the Lord's name is to be praised and let the whole earth be filled with his glory, amen, amen. ${ }^{42}$

The composer compiled verses from different sources to describe Christ as the glorious king of the world. ${ }^{43}$ Two of the citations can be associated with the liturgy of the feasts of Epiphany and Christmas, and indeed the mass formula for the feast of Epiphany was used during Charles's coronation on 23 October $1520 .{ }^{41}$ The choice of Epiphany Propers for the coronations of kings, and also for the Aachen coronation, had a long tradition and was associated with the homage paid to the newborn Christ by the wise men from the East. ${ }^{42}$ This tradition was very popular in the late Middle Ages and Renaissance and symbolized a direct identification of kings and ruling families with the holy kings; as a consequence, it also represented the concept of absolute homage to Christ. ${ }^{43}$ Thus the only link between the text of the motet and the Bologna coronation is the use of the Introit for Christmas.

Festa's use of the formula 'Christus vincit', which was out of fashion and did not exist in the strict papal ceremonial at that time, may have been caused by the current political situation. After the sack of Rome, the pope's political role was undermined. By sounding a 'Christus vincit' cantus firmus in the motet, the pope admitted to Charles's imperial independence, and the direct connection between Christ and the emperor was now emphasized. ${ }^{44}$ Thus the use of the word 'dominator' at the beginning of the motet has a symbolic meaning and can be also understood in reference to the emperor himself. Since certain words, such as 'dominator' and 'a solis ortu ad occasum', are repeated in individual voices, it does not seem unreasonable

4I Pietschmann quotes after Hartmann Maurus, 'As the archibishop of Cologne began the Introit of the mass, the royal singers in the middle of the choir began to sing: Ecce advenit dominator deus. [then] Kyrie eleison, [then] Alleluia, Vidimus stellam'; K. Pietschmann, op. cit., p. 329.

42 Ibid., p. 329 .

43 Ibid., pp. 330-33I.

44 Ibid., pp. 340-34I. 
to suppose that the motet glorifies the emperor. ${ }^{45}$ Pietschmann suggests that Festa's motet is supplemented by the motet Coronat pontifex by Adrian Thiebault, which was probably intended to highlight the pope's role and 'to place him on a hierarchical level equal to that of the emperor'. ${ }^{46}$ If so, these two pieces may have been performed one after another during the coronation ceremony. ${ }^{47}$

On the other hand, it is well known that the Advent liturgy was very often used in the context of the royal entry ceremony. In her detailed examination of Johannes Brassart's motet $O$ rex Fridrice / In tuo adventu - a musical tribute to the new king Frederick, the Habsburg Duke of Austria - Catherine Saucier indicates that the motet text contains some subtleties and dualities which can be read and understood only through the concept of adventus; ${ }^{48}$ in the medieval rituals, the ruler's arrival was often interpreted as analogous to the advent of the Christian Messiah. Ernst H. Kantorowicz says that:

both king and city are transformed as they approach one another; every terrestial city becomes another Jerusalem at the Advent of the Anointed, and the ruler at this entry becomes more and more a likeness of Christ. In other words, the liturgical celebration of an Adventus reflects, or even stages, the Christian prototype of Messianic entries, that is, the Lord's triumphant Entry as king into Jerusalem on Palm Sunday. ${ }^{49}$

Thus it should not be surprising that in several fifteenth-century compositions of this type, similar to Brassart's, one may find some references and allusions to the liturgical season of Advent; this is probably caused by the fact that in many chants sung during the Advent season the image of Christ as both earthly and heavenly King recurs repeatedly. ${ }^{50}$ Moreover, in at least a few Advent chants Christ, appears as peacemaker or protector. ${ }^{5 \mathrm{I}}$ In Brassart's motet this is revealed by a textual distinction: while the tenor voice pleads for deliverence from sin at the Saviour's arrival, the upper voices ask for peace..$^{52}$

Now let us go back to the problem of textual changes in Dominator caelorum, as they may help us to determine the actual function and use of the work and even an approximate date of the motet's first performance. As we already noticed elsewhere, the most conspicuous change appears at the beginning, where 'Domine Deus, qui conteris bella ab initio' was replaced by 'Dominator caelorum et terrae creator qui conteris bella ab initio'. Why did Festa do that? I think the composer made this change on purpose. It is well known that Festa (of course not only Festa but many

Ibid. $\mathrm{p} .342$.

Catherine Saucier, 'Acclaiming Advent and adventus in Johannes Brassart's motet for Frederick III', Early Music History 27 (2008), pp. 137-I79; for the motet text see esp. pp. I42-I43.

49 Ernst H. Kantorowicz, 'The "King's advent": And the enigmatic panels in the doors of Santa Sabina', The Art Bulletin 26 (1944) no. 4, pp. 207-231 at 210.

50 C. Saucier, op. cit., p. I48.

$5 \mathrm{I}$ Ibid., p. I5O.

52 Ibid., p. I47. 
other composers as well) had a special preference for treating some of his texts in such a way. While discussing Festa's Super flumina Babylonis, Lowinsky pointed out that:

when a composer of this era chooses the text for a single composition from many disparate parts of the Bible, when he thus constructs a text that occurs neither in the liturgy nor anywhere else, he obviously wishes to say, this is a unique text; it fits a unique situation; look into the sources of the text and you may find the key to its meaning. ${ }^{53}$

[...] The selection of the text from [...] different sources [...] was prompted by the composer's desire to hint at the occasion for which the work was written and the circumstances surrounding it. ${ }^{54}$

These slight changes made by Festa in the text of the third responsory may help us to determine the context in which the motet may have been performed for the first time. First of all, it is striking that he does not use the word 'Deus' in the first verse while other composers who set this text stick to it (the word 'Deus' only appears near the end of the motet in the prayer for peace). The reason for this may be that by using the phrase 'Dominator caelorum et terrae creator' the composer wanted it to evoke double connotations, adequate both to the new liturgical context and to a specific occasion for which the motet may have been intended. This occasion may have been a meeting of Charles V with Clement VII in Bologna in late 1529 and early I530.55 This new phrase in the motet text can be interpreted as a direct reference to Christ and at the same time also as a symbolic reference to the emperor. Such a dual rendering of the first phrase and the whole motet does not seem to be unreasonable, especially if we still keep in mind what was said about Festa's motet Ecce advenit dominator and its associations with the liturgies of the feasts of Epiphany and Christmas in the context of imperial coronations.

Undoubtedly the motet Dominator caelorum is a prayer to Christ for peace and protection against the enemies, and it could refer to many historical situations before I530 in Italy. On the other hand, it does not have direct references to Christ's coming, and thus no parallels to medieval royal/imperial entry can be made. But when we take into consideration all we have said so far, the meeting of Charles and Clement in Bologna still seems to be a likely occasion for the motet. Although Dominator caelorum may not have been performed at Charles's arrival in Bologna, it does not seem unreasonable to suggest that there were numerous other occasions for musical performances during his stay in the city. ${ }^{56}$ Unlike Ecce advenit dominator, which is found for the first time in the source RVat 20 and could have been composed for some other occasions besides Charles V's coronation, Dominator caelorum was

53 The Medici Codex of I5I8: A choirbook of motets dedicated to Lorenzo de' Medici, Duke of Urbino, ed. Edward E. Lowinsky, Chicago 1968, vol. I, p. 46.

54 Ibid., pp. 47-48.

55 It must be remembered that the meeting took place when Florence was still under the siege by imperial forces, which began in September 1529; the city surrendered on I2 August 1530.

56 For a description of various ceremonies that took place during Charles's and Clement's stay in Bologna at that time, see A. Cummings, op. cit., pp. I28-I39. 
copied into the Vallicelliana manuscript in 1530 or 1531 , and thus could not have been intented for any occasions after 1531. The first phrase 'Dominator caelorum et terrae creator' could have been introduced by Festa to refer to Emperor Charles V, as was shown in Ecce advenit dominator, in which the word 'dominator' has a symbolic meaning, and the image of the emperor as king of earth and heaven can emphasize his Christ-like attributes. Likewise in Advent chants, the use of the antiphon Da pacem in Altus II throughout Dominator caelorum and in the other voices near the end of the second movement might allude to Charles $\mathrm{V}$ as peacemaker and protector. This can only be understood in the context of the political situation at that time; as was mentioned elsewhere, Florence was besieged by the imperial forces, and this actually happened after the pope had decided to ask the emperor to intervene. Therefore, the motet can be interpreted as a prayer to Christ as well as a 'request' to the emperor for help to get rid of all those who opposed the return of Medici rule to Florence. The text from the Book of Judith, with symbolic and political connotations with the Medici family and current political situation, the middle voice expressing a hope for peace and the intentional textual change in the initial phrase and its possible dual rendering as referring to Christ and Charles $\mathrm{V}$ permit us to suppose that the motet may have been composed to honour Charles V during his meeting with Clement VII in Bologna.

The question arises of the authorship of Dominator caelorum. Who actually composed this motet - Festa or Conseil? Certainly the absence of Dominator caelorum

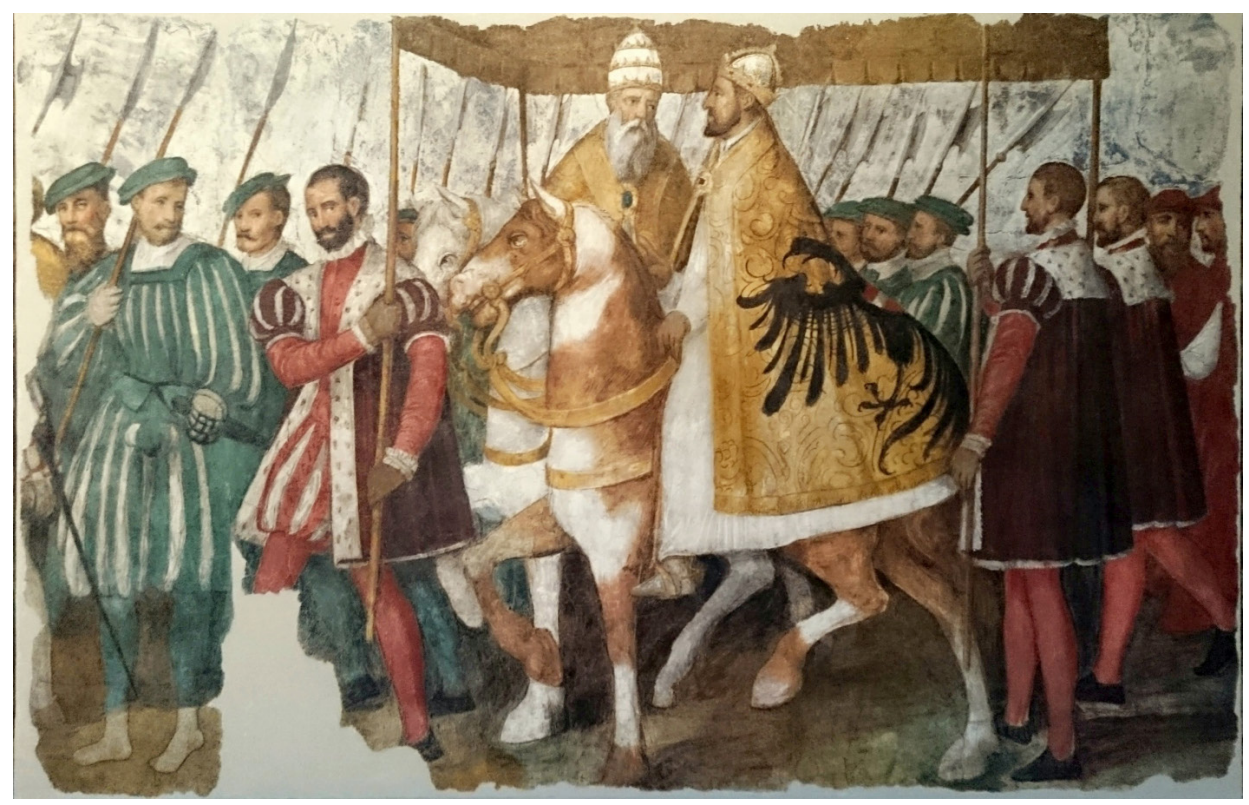

Fig. 3. Jacopo Ligozzi (1547-1627), Pope Clement VII and Emperor Charles V on horseback under a canopy (c.1580), Verona, Museo degli affreschi G.B. Cavalcaselle. The picture describes the entry of the Pope and the Emperor into Bologna in 5330 . Photo: public domain. 
in RVat 20 casts doubt on its attribution to Festa. Mitchell Brauner, in his thesis referring to the Vallicelliana partbooks, pointed out that:

it is possible that the scribe [of the Vallicelliana manuscript] was mistaken in this instance just as he was with the Ave regina celorum and the Ave regina celorum mater regis [these two pieces have conflicting attributions in other sources]. The source is not closer to one composer than the other; they were both in the employ of the Sistine Chapel. Also, given three attributions to Conseil in other sources, a scribal mistake in the Vallicelliana manuscript in the case of Dominator caelorum seems likely. It is possible, then, to place the motet among Conseil's works with a reasonable degree of confidence. ${ }^{57}$

Interestingly enough, Dominator caelorum still appears as anonymous in the Ferrarese manuscript called the Meijer partbook, copied by the famous scribe Jean Michel. Because all the pieces in this partbook are actually transmitted anonymously, their ascriptions are taken from the Catalogus Estensium. ${ }^{58}$ Since there are four motets by Conseil (Dominator caelorum is followed by one of them - Beatus Apostolus Andreas), and their ascriptions to the composer were based on their concordances and ascriptions in Catalogue Estensium, one may suppose that this attribution to Conseil is strong.

We know the possible reason for which Festa's motet Florentia was omitted from the manuscript VatS 20. But since Festa's Ecce advenit dominator is included there, it seems difficult to find a reason why Dominator caelorum is absent from the manuscript. Of course one may say that it was Festa's caprice not to provide Parvus with this motet and there is no particular reason behind it. But such a possible scenario cannot be ignored; Festa and Conseil spent most of their life in the papal chapel and composed motets based on the same texts: Deus venerunt gentes, probably written in response to the sack of Rome in 1527,59 as well as Lumen ad revelationum / Nunc Dimittis. Thus if Ecce advenit dominator was really composed by Costanzo Festa, a papal composer, and performed at the meeting between Charles V and Clement VII in Bologna, as Pietschmann persuasively demonstrates, could not Dominator caelorum have been Conseil's small musical contribution to this event? If so, it may have been Conseil who composed Dominator caelorum to embellish the Bologna meeting as Festa did by composing Ecce advenit dominator.

57 Mitchell Brauner, Jean du Conseil (Johannes Consilium): His life and motets, MA thesis, Brandeis University I978, p. I8.

58 This catalogue, owned by the Este family and compiled between I754 and 1757 by Pellegrino Niccolò Loschi and Giovanni Antonio Panelli, describes three now lost sixteenth-century partbooks, and their contents match those of the Meijer partbook in detail; see E. Jas, op. cit. (see n. 4), pp. 37-38.

59 J.T. Brobeck, op. cit. (see n. 3), pp. 394-395. 
FLORENCJA, PAPIEŻ KLEMENS VII I CESARZ KAROL V. STUDIUM KONTEKSTUALNE MOTETU „DOMINATOR CAELORUM” JEANA CONSEILA/COSTANZA FESTY (?)

Costanzo Festa (ok. I490-I545) i Jean Conseil (ok. I498-I534) spędzili większość swojego życia działając obok siebie w kapeli papieskiej i byli autorami motetów opartych na tych samych tekstach: Deus venerunt gentes, skomponowanych prawdopodobnie pod wpływem tragicznych wydarzeń z maja 1527 r., kiedy to niemiecko-hiszpańskie wojska Karola V zdobyły i złupiły Rzym, a także kompozycji do tekstu Lumen ad revelationum/Nunc Dimittis. Pięciogłosowy motet Dominator caelorum w różnych źródłach przypisywany jest obydwu kompozytorom, i chociaż został opublikowany w Opera Omnia Festy, bardzo często wymieniany jest jednak jako kompozycja Jeana Conseila. Na podstawie zaobserwowanych zmian w warstwie tekstowej i politycznego kontekstu towarzyszącego powstaniu motetu, sugeruję, że kompozycja ta być może została faktycznie skomponowany przez Francuza jako osobisty wkład w uświetnienie spotkania Karola V i papieża Klemensa VII w Bolonii na przełomie I529 i I 530 roku. Jeśli zatem motet Festy Ecce advenit dominator - jak to przekonująco przedstawił Klaus Pietschmann został skomponowany na tę samą uroczystość, to być może obydwa utwory - Ecce advenit dominator i Dominator caelorum - należałoby traktować jako kolejny dowód współpracy i przyjaznej rywalizacji dwóch wybitnych kompozytorów działających w kapeli papieskiej w I poł. XVI wieku.

Wojciech Odoj

Keywords / słowa klucze: Costanzo Festa, Jean Conseil, motet Dominator caelorum, Florence / Florencja, Bologna / Bolonia, Pope Clement VII / papież Klemens VII, Emperor Charles V / cesarz Karol V, Book of Judith / Księga Judyty.

Wojciech Odoj, PhD, is an Assistant Professor of Musicology at the University of Wrocław. His main research interest is music of the 15th and 16th centuries (especially Josquin des Prez) and relationships between music, liturgy, and other arts.

wojtekodoj@poczta.onet.pl

\section{Archiwalne zeszyty „Muzyki”}

www.ispan.pl/pl/wydawnictwa/czasopisma

iswydawnictwo@ispan.pl 